

\section{AGRICULTURAL SCIENCE}

Obituary

- OBITUARY - Professor Theresa (Terry) A. S. Aveling

Climate Change and Agriculture Research Paper

- Mineralization of bagged pruning waste in agrosystem on the subtropical coast of Andalusia (Spain)

M. P. REYES-MARTÍN, M. L. MARTÍNEZ-CARTAS, I. ORTIZ-BERNAD, L. M. SAN-EMETERIO AND E. FERNÁNDEZ-ONDOÑO

Crops and Soils Research Papers

- Scanning electron microscopy observations of pollen morphology in common vetch (Vicia sativa) subspecies RUI DONG, ZHONGJIE LU, ZHENGYU YANG, YANRONG WANG AND CHAO CHEN

- How will future climate depending agronomic management impact the yield risk of wheat cropping systems? A regional case study of Eastern Denmark

J. MACHOLDT, J. GLERUP GYLDENGREN, E. DIAMANTOPOULOS AND M. E. STYCZEN

- A new empirical equation to describe the vertical leaf distribution profile of maize P. P. FAN, Y. Y. LI, J. B. EVERS, B. MING, C. X. WANG, S. K. LI AND R. Z. XIE

- Soil organic carbon storage by shaded and unshaded coffee systems and its implications for climate change mitigation in China ZIWEI XIAO, XUEHUI BAI, MINGZHU ZHAO, KAI LUO, HUA ZHOU, GUANRUN MA, TEIYING GUO, LINLIN SU AND JINHONG LI

Oat genotypic requirement for intercropping with vetch under Mediterranean conditions D. BAXEVANOS, I. T. TSIALTAS, O. VOULGARI, C. I. PANKOU, D. VLACHOSTERGIOS AND A. S. LITHOURGIDIS

- Nitrogen fertilizer value of animal slurries with different proportions of liquid and solid fractions: A 3-year study under field conditions BETINA NØRGAARD PEDERSEN, BENT T. CHRISTENSEN, LUCA BECHINI, DANIELE CAVALLI, JØRGEN ERIKSEN AND PETER SØRENSEN

- Evaluating irrigated rice yields in Japan within the Climate Zonation Scheme of the Global Yield Gap Atlas S. ISHIIKAWA, T. NAKASHIMA, T. IIZUMI AND M. C. HARE

- Functional soil organic matter fractions in response to long-term fertilizer management in a double-cropping paddy field of southern China HAIMING TANG, CHAO LI, LIHONG SHI, LI WEN, KAIKAI CHENG, WEIYAN LI AND XIAOPING XIAO

- Comprehensive yield gap analysis and optimizing agronomy practices of soybean in Iran A. NEHBANDANI, A. SOLTANI, A. HAJJARPOOR, A. DADRASI AND F. NOURBAKHSH

Animal Research Papers

- Effects of different barley grain preservation techniques on intake, growth and carcase traits of finishing dairy bulls fed grass silage-based rations A. HUUSKONEN, M. RINNE AND K. MANN

- In situ techniques to predict in vivo digestibility and to evaluate the impact of flint maize processing methods on degradation parameters

L. A. GODOI, B. C. SILVA, A. C. B. MENEZES, F. A. S. SILVA, H. M. ALHADAS, N. V. TRÓPIA, J. T. SILVA

D. R. ANDRADE, J. P. SCHOONMAKER AND S. C. VALADARES FILHO

Effect of protein level and grain source on milk production, nutrient digestibility and ruminal fermentation in primiparous Holstein cows

H. MIRZAEI-ALAMOUTI, A. MOHAMMAD, M. VAZIRIGOHAR, P. REZAMAND AND M. MANSOURYAR

- Variation in PLIN2 and its association with milk traits and milk fat composition in dairy cows Y. H. LI, H. ZHOU, L. CHENG, J. ZHAO AND J. G. H. HICKFORD

Goats fed with non-protein nitrogen: ruminal bacterial community and ruminal fermentation, intake, digestibility and nitrogen balance

A.S.M. LOPES, J.S. DE OLIVEIRA, E.M. SANTOS, A.N. MEDEIROS, P.E.N. GIVISIEZ, M.L.P. LEMOS, F.N.S. SANTOS, N.M.V. SILVA, P.S. AZEVEDO, L.S. SOUSA, D.M. PEREIRA AND C.J.B. OLIVEIRA

Submit your paper online

mc.manuscriptcentral.com/jagricsci

Register to receive the latest news and content from the journal

https://www.cambridge.org/core/journals/ journal-of-agricultural-science 